\title{
BMJ Open Change in prevalence of chronic kidney disease in England over time: comparison of nationally representative cross-sectional surveys from 2003 to 2010
}

\author{
Grant R Aitken, ${ }^{1}$ Paul J Roderick, ${ }^{2}$ Simon Fraser, ${ }^{2}$ Jennifer S Mindell, ${ }^{3}$ \\ Donal O'Donoghue, ${ }^{4}$ Julie Day, ${ }^{5}$ Graham Moon ${ }^{1}$
}

To cite: Aitken GR,

Roderick PJ, Fraser S, et al.

Change in prevalence of

chronic kidney disease in

England over time:

comparison of nationally representative cross-sectional surveys from 2003 to 2010. BMJ Open 2014;4:e005480. doi:10.1136/bmjopen-2014005480

- Prepublication history and additional material is available. To view please visit the journal (http://dx.doi.org/ 10.1136/bmjopen-2014005480).

Received 14 April 2014 Accepted 5 September 2014

\section{CrossMark}

For numbered affiliations see end of article.

Correspondence to Professor Paul J Roderick; pj@@soton.ac.uk

\section{ABSTRACT}

Objectives: To determine whether the prevalence of chronic kidney disease (CKD) in England has changed over time.

Design: Cross-sectional analysis of nationally representative Health Survey for England (HSE) random samples.

Setting: England 2003 and 2009/2010.

Survey participants: 13896 adults aged 16+ participating in HSE, adjusted for sampling and non-response, 2009/2010 surveys combined.

Main outcome measure: Change in prevalence of estimated glomerular filtration rate (eGFR) $<60 \mathrm{~mL} / \mathrm{min} /$ $1.73 \mathrm{~m}^{2}$ (as proxy for stage 3-5 CKD), from 2003 to 2009/2010 based on a single serum creatinine measure using an isotope dilution mass spectrometry traceable enzymatic assay in a single laboratory; eGFR derived using Modified Diet in Renal Disease (MDRD) and Chronic Kidney Disease Epidemiology

Collaboration (CKDEPI) eGFR formulae.

Analysis: Multivariate logistic regression modelling to adjust time changes for sociodemographic and clinical factors (body mass index, hypertension, diabetes, lipids). A correction factor was applied to the 2003 HSE serum creatinine to account for a storage effect.

Results: National prevalence of low eGFR $(<60)$ decreased within each age and gender group for both formulae except in men aged 65-74. Prevalence of obesity and diabetes increased in this period, while there was a decrease in hypertension. Adjustment for demographic and clinical factors led to a significant decrease in CKD between the surveyed periods. The fully adjusted $\mathrm{OR}$ for eGFR $<60 \mathrm{~mL} / \mathrm{min} / 1.73 \mathrm{~m}^{2}$ was 0.75 (0.61 to 0.92) comparing 2009/2010 with 2003 using the MDRD equation, and was similar using the CKDEPI equation 0.73 ( 0.57 to 0.93 ).

Conclusions: The prevalence of a low eGFR indicative of CKD in England appeared to decrease over this 7-year period, despite the rising prevalence of obesity and diabetes, two key causes of CKD. Hypertension prevalence declined and blood pressure control improved but this did not appear to explain the fall.

\section{Strengths and limitations of this study}

- This study used nationally representative samples, with later Health Surveys for England (HSEs) pooled over 2 years to increase the numbers and precision of estimates. The surveys used standardised protocols for measurement by trained interviewers and nurses, with all samples tested in the same laboratory with standardised assays.

- The analyses enable a longitudinal comparison of chronic kidney disease (CKD) estimates across different age-sex groupings and the application and comparison of the two equations to derive the estimated glomerular filtration rate (eGFR). Weighting was introduced for both surveyed periods to reduce response bias and account for missing data. A correction factor was applied to the 2003 HSE data to adjust for the shift in measured creatinine due to sample storage.

- The study was limited by the cross-sectional nature of the HSE, which restricts the ability to infer causal relationships from the associations identified. The study was also limited by the use of a single sample to test for serum creatinine in each survey; therefore, the persistence of reduced eGFR levels to confirm chronicity cannot be shown.

- The prevalence of stage 4/5 CKD is likely to be underestimated as the HSE may not fully account for some people in whom more severe CKD (stage $4 / 5$ ) will be more common.

- The absence of albuminuria data in the 2003 HSE is another major limitation, given its strong independent association with adverse outcomes and its use to stratify risk for prevention and management (eg, use of renin-angiotensin system inhibition).

Periodic assessment of eGFR and albuminuria in future HSEs is needed to evaluate trends in CKD. 


\section{INTRODUCTION}

Chronic kidney disease (CKD) is recognised as a global public health problem. ${ }^{1}$ CKD is defined and staged using the estimated glomerular filtration rate (eGFR) and markers of kidney damage, mainly albuminuria. ${ }^{2}$ Both eGFR and albuminuria are strong independent risk factors for all-cause and cardiovascular disease (CVD) mortality, and progression to end-stage renal disease (ESRD), which may require renal replacement therapy (RRT) by dialysis or transplantation. ${ }^{3}$ In 2010 in England, the prevalence of RRT was 832 per million population, a 3\% increase from 2009; the National Health Service (NHS) costs of RRT were estimated at $£ 780$ million for $2009 / 2010$, and the total cost at $£ 1.45$ billion, a nearly threefold increase on estimated costs for 2002. ${ }^{4}$

The population prevalence of CKD in England was reported for the first time using data on eGFR and albuminuria in the nationally representative Health Surveys for England (HSEs) 2009 and 2010, though there had previously been estimates based on routine testing using primary care data. ${ }^{6}$ In the combined 2009/2010 HSEs, $6 \%$ of men and $7 \%$ of women had eGFR $<60 \mathrm{~mL} / \mathrm{min} /$ $1.73 \mathrm{~m}^{2}$ (equivalent to CKD stage $3-5$ if chronic) with a strong age gradient. $^{8}$ The prevalence of low eGFR increased in the USA, based on National Health and Nutrition Examination (NHANES) surveys between 1988 and 2004, even after adjusting for adverse trends in risk factors (obesity, diabetes, hypertension), but little is known about CKD prevalence trends in England..$^{9-11}$

Information on prevalence change is needed to assess the impact of trends in underlying determinants, and of strategies to prevent and manage CKD. Several policy initiatives have been introduced in England that have had an impact on the prevention, detection and management of CKD. The National Service Framework for Renal Services 2004/2005 led to the national reporting of eGFR by clinical biochemistry laboratories from $2006,{ }^{12}$ the General Practice pay for performance Quality Outcomes Framework (QOF) included targets for CKD management from 2006/2007, ${ }^{13}$ and the NHS Vascular Checks Programme, introduced in 2009, includes screening for CKD (stage 3-5) in people aged 35-74 with newly identified type 2 diabetes or hypertension. ${ }^{14}$ This study therefore aimed to compare the prevalence of CKD in HSE 2003 with the combined 2009/ 2010 HSEs and to relate this to any changes in prevalence of risk factors for CKD, particularly obesity, diabetes and hypertension, over this period.

\section{METHODS}

Full details of the conduct of the HSE, and the measurement of non-CKD variables and response rates, are shown in the 2003 and 2009 Health Survey for England reports. ${ }^{15} 16$ Survey participants within private households were selected using a multistage stratified random probability sample. Household response rates were $73 \%$ in HSE 2003 and 68\%/66\% in HSE 2009/2010. In co-operating households, $90 \%$ and $89 \% / 86 \%$ of adults completed an interview questionnaire while $70 \%$ and $62 \% / 57 \%$ consented to a nurse visit, of whom $74-76 \%$ provided a blood test. The HSE 2003 contained 18533 individuals, and data from HSE 2009 and HSE 2010 were combined to provide a sample size of 13065 individuals. This totalled 31598 individuals for the combined 2003, 2009 and 2010 HSEs. Eligible participants were individuals aged 16 and older who had a valid serum creatinine value. This left 7850 individuals from the 2003 HSE and 6046 individuals from the combined 2009/2010 HSEs, a total of 13896 individuals for analysis.

Age was grouped into five categories: 16-34, 35-54, 55-64, 65-74 and 75+. There were four separate ethnic groupings: White, South Asian, Black and Other. Socioeconomic factors included: (1) occupationNational Statistics Socio-Economic Classification (NS-SEC, divided into three categories: managerial and professional occupations, intermediate occupations and routine and manual occupations); (2) qualifications grouped as: degree or equivalent; below degree (other qualification) and none (no qualification); (3) household tenure (own vs renting) and (4) access to motor vehicle (none vs any).

Smoking status was defined as current, ex-smoker or never smoked. Hypertension was defined as doctordiagnosed (pre-existing diagnosis), survey-defined (identified as having high blood pressure (BP, systolic $\geq 140 \mathrm{~mm} \mathrm{Hg}$ and/or diastolic $\geq 90 \mathrm{~mm} \mathrm{Hg}$ and/or taking medication for hypertension) at the survey examination), and 'total' (doctor+survey diagnosed). Survey-defined diabetes was glycated haemoglobin (HBA1c) $\geq 6.5 \%$ at nurse visit. HBA1c data are presented for those with and without diagnosed diabetes. Body mass index (BMI) was defined as normal $\left(<25 \mathrm{~kg} / \mathrm{m}^{2}\right)$, overweight $\left(\geq 25\right.$ and $\left.<30 \mathrm{~kg} / \mathrm{m}^{2}\right)$ and obese $\left(\geq 30 \mathrm{~kg} / \mathrm{m}^{2}\right)$. Waist circumference was classified as: $<94,94-102$ (high) and $>102 \mathrm{~cm}$ (very high) for men, and $<80,80-88$ (high) and $>88 \mathrm{~cm}$ (very high) for women. For South Asian men, the waist circumference was classified as: $<90,90$ 102 (high) and $>102 \mathrm{~cm}$ (very high). High-density lipoprotein (HDL) cholesterol and total cholesterol were treated as continuous variables.

To investigate medication use, we examined the use of diuretics, $\beta$-blockers, renin-angiotensin system (RAS) inhibitors (ACE inhibitors and angiotensin receptor blockers (ARBs)), calcium-channel blockers, other antihypertensives in those with doctor-diagnosed hypertension, doctor-diagnosed diabetes and eGFR $<60 \mathrm{~mL} /$ $\min / 1.73 \mathrm{~m}^{2}$, and use of lipid lowering drugs (the majority of which are statins) in the whole population. In 2003, $47 \%$ of respondents answered yes to whether they were taking any prescribed medication, and $50 \%$ in 2009/2010.

Serum creatinine was assayed using an isotope dilution mass spectrometry (IDMS) traceable enzymatic assay in 
a single laboratory (Clinical Biochemistry Department at the Royal Victoria Infirmary, Newcastle Upon Tyne). Both the Modified Diet in Renal Disease (MDRD) equation (in routine use in the UK) and the newer Chronic Kidney Disease Epidemiology Collaboration (CKDEPI) equation (which provides better risk prediction and is recommended for use in international guidelines) were used to define CKD. ${ }^{2}{ }^{17}$ eGFR values were derived using the standard equations. ${ }^{18} 19$

Details of laboratory analysis, internal quality control and external quality assurance are provided in the HSE 2009/2010 documentation, with these methods replicated in analysis of the 2003 HSE samples. ${ }^{8}$

Samples were assayed for serum creatinine over a 19-month period with two different batches of the trilevel Internal Quality Control (IQC) material. HSE 2009 and 2010 samples were analysed with Batch 1 or Batch 2 IQC, while HSE 2003 samples were analysed with Batch 2 IQC. The creatinine assay was stable over time with IQC results very close to the expected target values. Batch 1 IQC gave mean (SD) creatinine concentrations of $56(0.6), 167(1.3)$ and $586(4.9) \mu \mathrm{mol} / \mathrm{L}$ for levels 1 , 2 and 3, respectively, compared with target means of 56 , 167 and $588 \mu \mathrm{mol} / \mathrm{L}$. Batch 2 material gave mean(SD) creatinine concentrations of 51 (1.1), 175 (2.2) and 597 (5.6) $\mu \mathrm{mol} / \mathrm{L}$ for levels 1,2 and 3, respectively, compared with target means of 51, 175 and $599 \mu \mathrm{mol} / \mathrm{L}$.

The HSE 2003 samples had been stored, frozen at $-40^{\circ} \mathrm{C}$, and then thawed for measurement in 2010 . Although such freezing is not thought to affect creatinine levels, ${ }^{20}$ we undertook a reanalysis in 2014 of a random sample of 500 serum creatinine samples taken from the 2009 HSE and subsequently frozen and stored under the same conditions as the HSE 2003 samples, stratified by quintile, to determine if there was a shift in measured creatinine on storage. We found that mean serum creatinine increased on storage and was best predicted by a regression equation where the original 2009 serum creatinine value without storage equalled 0.303 plus 0.94 multiplied by the stored serum creatinine value. We assumed that the same effect applied to the 2003 serum creatinine data which were analysed in 2009-2010, and we applied the same adjustment. This decreased the 2003 serum creatinine values. eGFR was classified as below $60 \mathrm{~mL} / \mathrm{min}$ / $1.73 \mathrm{~m}^{2}$ or equal to or greater than $60 \mathrm{~mL} / \mathrm{min} / 1.73 \mathrm{~m}^{2}$. We compared the change in mean serum creatinine in people aged 20-39 without any diabetes or any hypertension as per Coresh et al. ${ }^{9}$

\section{STATISTICS}

Patient characteristics were compared between the 2003 and $2009 / 2010$ HSEs using $\chi^{2}$ tests for categorical variables and Mann-Whitney $\mathrm{U}$ tests for non-normally distributed continuous variables. eGFR $<60 \mathrm{~mL} / \mathrm{min}$ / $1.73 \mathrm{~m}^{2}$ prevalence in 2003 and $2009 / 2010$ was compared across age and sex groupings. BP levels were compared in all participants, in those with diagnosed hypertension and in those with eGFR $<60 \mathrm{~mL} / \mathrm{min} /$ $1.73 \mathrm{~m}^{2}$; HBA1c was compared in all participants and in those with doctor-diagnosed diabetes. Binary logistic regression models were used to examine the relationships between eGFR $<60 \mathrm{~mL} / \mathrm{min} / 1.73 \mathrm{~m}^{2}$ and age, sex and socioeconomic and clinical factors to determine if there were significant differences between the two survey periods. The dependent variables were CKDEPI and the MDRD equation eGFR $<60 \mathrm{~mL} / \mathrm{min} / 1.73 \mathrm{~m}^{2}$ (indicative of stage 3-5 CKD). Four models were produced for each: (1) age-sex adjusted; (2) model 1 plus socioeconomic status and ethnicity; (3) model 2 plus behavioural, lipid levels (HDL and total cholesterol) and clinical variables except hypertension and (4) model 3 plus doctor-diagnosed hypertension. Interactions between period and both diabetes and hypertension were tested.

Sensitivity analyses were performed by replacing doctor-diagnosed diabetes with HBA1c, replacing doctor-diagnosed hypertension with diastolic and systolic $\mathrm{BP}$ and adjusting for lipid lowering agents in the full model. Non-response and blood sample weights were used in all analyses to address issues with missing individuals who did not have a blood sample taken and sent to the laboratory for analysis to determine the serum creatinine value. Full details on how the weights were obtained are provided in the final volume of the HSE report each year. The age, education and smoking status of those interviewed, having a nurse visit and having a blood test is similar once non-response is taken into account (data not shown). All analyses were performed using IBM SPSS Statistics V.20.

\section{RESULTS}

The final sample for the study comprised 13896 individuals aged $16+$ who had a valid serum creatinine value. Comparing the characteristics of these participants between the 2003 and 2009/2010 surveys, the age structure, gender, NS-SEC and car ownership were similar while the educational level improved and there was an increase in rented tenure (table 1). The prevalence of diabetes however classified increased, as did obesity. In contrast, smoking and hypertension prevalence decreased.

There were significant increases in BMI, waist circumference and HBAlc in the population, although there was no change in HBAlc in those with diagnosed diabetes (table 2). Median BP levels (systolic and diastolic) fell in all groups including those with diagnosed hypertension, doctor-diagnosed diabetes and eGFR $<60 \mathrm{~mL} /$ $\min / 1.73 \mathrm{~m}^{2}$. Median total and HDL cholesterol fell in men and women.

The distribution of serum creatinine is similar for 2003 and 2009/2010 (figure 1). Median serum creatinine increased slightly, leading to a very small nonsignificant decrease in median eGFR using MDRD and CKDEPI formulae (table 2). Mean serum creatinine for 
Table 1 Comparison of prevalence of categorical measures in 2003 and 2009/2010*

\begin{tabular}{|c|c|c|c|c|c|c|}
\hline \multirow[b]{2}{*}{ Variable } & \multirow[b]{2}{*}{ Category } & \multicolumn{2}{|l|}{2003} & \multicolumn{2}{|c|}{ 2009-2010 } & \multirow{2}{*}{$\begin{array}{l}\chi^{2} \text { Test } \\
\text { p Value }\end{array}$} \\
\hline & & Number & Per cent & Number & Per cent & \\
\hline All & Aged 16+ & $7850 \dagger$ & 100.0 & $6046 \dagger$ & 100.0 & - \\
\hline \multirow[t]{6}{*}{ Age } & $16-34$ & 2425 & 31.0 & 1847 & 30.6 & 0.44 \\
\hline & $34-54$ & 2790 & 35.7 & 2129 & 35.3 & \\
\hline & $55-64$ & 1126 & 14.4 & 886 & 14.7 & \\
\hline & $65-74$ & 813 & 10.4 & 639 & 10.6 & \\
\hline & $75+$ & 662 & 8.5 & 539 & 8.9 & \\
\hline & Missing & 0 & - & 0 & - & \\
\hline \multirow[t]{5}{*}{ Ethnicity } & White & 7226 & 92.5 & 5244 & 90.7 & $<0.001$ \\
\hline & South Asian & 332 & 4.3 & 243 & 4.2 & \\
\hline & Black & 144 & 1.8 & 154 & 2.7 & \\
\hline & Other & 108 & 1.4 & 139 & 2.4 & \\
\hline & Missing & 0 & - & 0 & - & \\
\hline \multirow[t]{3}{*}{ Sex } & Male & 3795 & 48.6 & 2961 & 49.0 & 0.80 \\
\hline & Female & 4020 & 51.4 & 3080 & 51.0 & \\
\hline & Missing & 0 & - & 0 & - & \\
\hline \multirow{4}{*}{ Qualification } & Degree & 1375 & 17.6 & 1295 & 22.5 & $<0.001$ \\
\hline & Below degree & 4551 & 58.3 & 3296 & 57.0 & \\
\hline & None & 1874 & 24.0 & 1191 & 20.6 & \\
\hline & Missing & 11 & - & 3 & - & \\
\hline \multirow[t]{4}{*}{ NS-SEC } & Highest & 2514 & 33.7 & 1894 & 34.8 & 0.43 \\
\hline & Middle & 1674 & 22.4 & 1203 & 22.1 & \\
\hline & Lowest & 3273 & 43.9 & 2343 & 43.1 & \\
\hline & Missing & 350 & - & 345 & - & \\
\hline \multirow[t]{3}{*}{ Car ownership } & Yes & 6460 & 82.7 & 4728 & 81.7 & 0.17 \\
\hline & No & 1348 & 17.3 & 1056 & 18.3 & \\
\hline & Missing & 2 & - & 1 & - & \\
\hline \multirow{3}{*}{ Tenure } & Own & 5878 & 75.4 & 3955 & 68.5 & $<0.001$ \\
\hline & Rent & 1914 & 24.6 & 1817 & 31.5 & \\
\hline & Missing & 11 & - & 13 & - & \\
\hline \multirow[t]{4}{*}{ Smoking } & Current & 1960 & 25.2 & 1210 & 21.0 & $<0.001$ \\
\hline & Ex & 1877 & 24.1 & 1429 & 24.8 & \\
\hline & Never & 3951 & 50.7 & 3126 & 54.2 & \\
\hline & Missing & 22 & - & 20 & - & \\
\hline \multirow[t]{4}{*}{ Body mass index } & Normal/underweight $\left(<25 \mathrm{~kg} / \mathrm{m}^{2}\right)$ & 2867 & 39.2 & 1956 & 36.8 & $<0.001$ \\
\hline & Overweight $\left(25-30 \mathrm{~kg} / \mathrm{m}^{2}\right)$ & 2868 & 39.2 & 2047 & 38.5 & \\
\hline & Obese $\left(>30 \mathrm{~kg} / \mathrm{m}^{2}\right)$ & 1587 & 21.7 & 1314 & 24.7 & \\
\hline & Missing & 489 & - & 469 & - & \\
\hline \multirow[t]{4}{*}{ Waist circumference } & Low (<94 cm male, $<80 \mathrm{~cm}$ female) & 3060 & 39.8 & 2120 & 37.1 & $<0.001$ \\
\hline & High (94-102 cm male, $80-88 \mathrm{~cm}$ female) & 1929 & 25.1 & 1347 & 23.6 & \\
\hline & Very High ( $>102 \mathrm{~cm}$ male, $>88 \mathrm{~cm}$ female) & 2703 & 35.1 & 2242 & 39.3 & \\
\hline & Missing & 118 & - & 77 & - & \\
\hline \multirow[t]{3}{*}{ Doctor-diagnosed diabetes } & Yes & 305 & 3.9 & 322 & 5.3 & $<0.001$ \\
\hline & No & 7504 & 96.1 & 5715 & 94.7 & \\
\hline & Missing & 6 & - & 2 & - & \\
\hline \multirow[t]{3}{*}{ Survey-diagnosed diabetes } & Yes (HBA1c $\geq 6.5 \%)$ & 296 & 3.8 & 316 & 5.5 & $<0.001$ \\
\hline & No $(\mathrm{HBA} 1 \mathrm{c}<6.5 \%)$ & 7401 & 96.2 & 5417 & 94.5 & \\
\hline & Missing & 113 & - & 52 & - & \\
\hline Total diabetes & Yes & 406 & 5.2 & 446 & 7.4 & $<0.001$ \\
\hline & No & 7405 & 94.8 & 5585 & 92.6 & \\
\hline & Missing & 0 & - & 0 & - & \\
\hline Doctor-diagnosed hypertension & Yes & 2118 & 27.2 & 1501 & 25.0 & 0.003 \\
\hline & No & 5662 & 72.8 & 4527 & 75.0 & \\
\hline & Missing & 36 & - & 10 & - & \\
\hline Survey-diagnosed hypertension & Yes & 2065 & 31.5 & 1545 & 29.2 & 0.02 \\
\hline & No & 4499 & 68.5 & 3744 & 70.8 & \\
\hline & Missing & 1246 & - & 496 & - & \\
\hline
\end{tabular}


Table 1 Continued

\begin{tabular}{|c|c|c|c|c|c|c|}
\hline \multirow[b]{2}{*}{ Variable } & \multirow[b]{2}{*}{ Category } & \multicolumn{2}{|l|}{2003} & \multicolumn{2}{|c|}{ 2009-2010 } & \multirow{2}{*}{$\begin{array}{l}\chi^{2} \text { Test } \\
\text { p Value }\end{array}$} \\
\hline & & Number & Per cent & Number & Per cent & \\
\hline \multirow[t]{3}{*}{ Total hypertension } & Yes & 2866 & 36.7 & 2062 & 34.2 & 0.004 \\
\hline & No & 4933 & 63.3 & 3968 & 65.8 & \\
\hline & Missing & 12 & - & 0 & - & \\
\hline \multirow[t]{3}{*}{ eGFR CKDEPI } & $<45\left(\mathrm{~mL} / \mathrm{min} / 1.73 \mathrm{~m}^{2}\right)$ & 142 & 1.8 & 81 & 1.4 & 0.07 \\
\hline & $<60\left(\mathrm{~mL} / \mathrm{min} / 1.73 \mathrm{~m}^{2}\right)$ & 444 & 5.7 & 303 & 5.2 & 0.26 \\
\hline & Missing & 0 & - & 0 & - & \\
\hline \multirow[t]{3}{*}{ eGFR MDRD } & $<45\left(\mathrm{~mL} / \mathrm{min} / 1.73 \mathrm{~m}^{2}\right)$ & 146 & 1.9 & 80 & 1.4 & 0.03 \\
\hline & $<60\left(\mathrm{~mL} / \mathrm{min} / 1.73 \mathrm{~m}^{2}\right)$ & 521 & 6.7 & 349 & 6.0 & 0.13 \\
\hline & Missing & 0 & - & 0 & - & \\
\hline \multicolumn{7}{|c|}{$\begin{array}{l}\text { Bold typeface indicates significance at } p<0.05 . \\
\text { *Weighted for non-response (unless stated otherwise). } \\
\text { †Not weighted. } \\
\text { CKDEPI, Chronic Kidney Disease Epidemiology Collaboration; eGFR, estimated glomerular filtration rate; HBA1c, glycated haemoglobin; } \\
\text { MDRD, Modified Diet in Renal Disease; NS-SEC, National Statistics Socio-Economic Classification. }\end{array}$} \\
\hline
\end{tabular}

those aged 20-39 without doctor-diagnosed hypertension or diabetes increased slightly from $70.6 \mu \mathrm{mol} / \mathrm{L}$ $(\mathrm{SD} \pm 13.6)$ in 2003 to $71.4 \mu \mathrm{mol} / \mathrm{L}(\mathrm{SD} \pm 14.3)$ in $2009 /$ $2010(\mathrm{p}=0.09)$.

The proportion of individuals with MDRD $\mathrm{eGFR}<60 \mathrm{~mL} / \mathrm{min} / 1.73 \mathrm{~m}^{2}$ decreased from $6.7 \%$ in 2003 to $6 \%$ in $2009 / 2010(p=0.13)$ and in those with
eGFR $<45 \mathrm{~mL} / \mathrm{min} / 1.73 \mathrm{~m}^{2}$ from $1.9 \%$ to $1.4 \%$ $(\mathrm{p}=0.03)$. The corresponding figures for CKDEPI were $5.7 \%$ and $5.2 \%(\mathrm{p}=0.26)$ and $1.8 \%$ and $1.4 \%(\mathrm{p}=0.07)$, respectively. The prevalence of low eGFR fell in all age and gender groups and with either CKDEPI or MDRD equations, except in men aged 65-74 in whom there was a slight increase (figure 2).

Table 2 Weighed comparison of continuous measures in 2003 and 2009-2010

\begin{tabular}{|c|c|c|c|c|}
\hline Variable & Category & $\begin{array}{l}2003 \\
\text { Median value (IQR) }\end{array}$ & $\begin{array}{l}2009-2010 \\
\text { Median value (IQR) }\end{array}$ & $\begin{array}{l}\text { Mann-Whitney U test } \\
\text { p Value }\end{array}$ \\
\hline Serum creatinine $(\mu \mathrm{mol} / \mathrm{L})$ & Median value & $71.7(62.3-82.1)$ & $72.0(62.0-83.0)$ & 0.66 \\
\hline \multirow[t]{2}{*}{ eGFR $\left(\mathrm{mL} / \mathrm{min} / 1.73 \mathrm{~m}^{2}\right)$} & MDRD & $90.5(77.2-105.4)$ & $90.3(77.1-104.7)$ & 0.62 \\
\hline & CKDEPI & $99.3(84.1-113.9)$ & $98.6(84.0 .-112.5)$ & 0.11 \\
\hline \multirow[t]{3}{*}{ BMI $\left(\mathrm{kg} / \mathrm{m}^{2}\right)$} & All & $26.2(23.3-29.4)$ & $26.6(23.5-30.0)$ & $<0.001$ \\
\hline & Male & $26.6(24.0-29.4)$ & $27.0(24.2-29.9)$ & 0.001 \\
\hline & Female & 25.7 (22.7-29.5) & $26.1(23.1-30.0)$ & $<0.001$ \\
\hline \multirow[t]{3}{*}{ Waist circumference $(\mathrm{cm})$} & All & $90.6(81.1-100.0)$ & $92.0(81.6-101.7)$ & $<0.001$ \\
\hline & Male & $95.8(88.0-104.0)$ & $96.7(88.2-105.0)$ & 0.05 \\
\hline & Female & $84.6(76.4-94.0)$ & $86.3(77.3-96.7)$ & $<0.001$ \\
\hline \multirow[t]{5}{*}{ Systolic BP (mm Hg) } & All & $125.5(115.5-138.0)$ & $124.5(114.0-136.0)$ & $<0.001$ \\
\hline & Doctor-diagnosed HT & $135.5(124.0-149.5)$ & $134.0(122.2-145.5)$ & $<0.001$ \\
\hline & Doctor-diagnosed DM & $134.5(122.5-148.0)$ & $131.8(120.0-143.5)$ & $<0.001$ \\
\hline & eGFR<60 (CKDEPI) & $140.2(126.0-156.0)$ & $131.8(119.0-143.5)$ & $<0.001$ \\
\hline & eGFR<60 (MDRD) & $137.5(124.0-153.7)$ & $129.2(118.0-142.5)$ & $<0.001$ \\
\hline \multirow[t]{5}{*}{ Diastolic BP (mm Hg) } & All & $73.0(65.5-80.5)$ & 72.5 (65.5-80.) & $<0.001$ \\
\hline & Doctor-diagnosed HT & 77.5 (70.0-85.5) & $76.0(68.0-83.5)$ & $<0.001$ \\
\hline & Doctor-diagnosed DM & $72.0(64.5-80.5)$ & $71.50(64.5-78.5)$ & $<0.001$ \\
\hline & eGFR<60 (CKDEPI) & 71.5 (62.9-80.5) & $68.5(60.5-76.0)$ & $<0.001$ \\
\hline & eGFR<60 (MDRD) & $72.5(64.0-81.5)$ & $69.0(61.5-76.8)$ & $<0.001$ \\
\hline \multirow[t]{2}{*}{ Glycated Hb (\%) } & All & $5.20(5.00-5.50)$ & $5.30(5.10-5.70)$ & $<0.001$ \\
\hline & Doctor-diagnosed DM & $6.90(5.90-8.20)$ & $6.90(5.90-8.30)$ & 0.85 \\
\hline \multirow[t]{3}{*}{ HDL cholesterol (mmol/L) } & All & $1.50(1.20-1.70)$ & $1.40(1.20-1.70)$ & $<0.001$ \\
\hline & Male & $1.30(1.20-1.60)$ & $1.30(1.10-1.50)$ & $<0.001$ \\
\hline & Female & $1.60(1.40-1.90)$ & $1.60(1.30-1.90)$ & 0.046 \\
\hline \multirow[t]{3}{*}{ Total cholesterol (mmol/L) } & All & $5.40(4.70-6.20)$ & $5.20(4.40-5.90)$ & $<0.001$ \\
\hline & Male & $5.40(4.70-6.20)$ & $5.10(4.30-5.90)$ & $<0.001$ \\
\hline & Female & $5.40(4.70-6.20)$ & $5.20(4.50-6.00)$ & 0.001 \\
\hline
\end{tabular}

Bold typeface indicates significance at $p<0.05$.

BP, blood pressure; Hb, haemoglobin; CKDEPI, Chronic Kidney Disease Epidemiology Collaboration; DM, diabetes mellitus; eGFR estimated glomerular filtration rate; HDL, high-density lipoprotein; HT, hypertension; IQR, interquartile range; MDRD, Modified Diet in Renal Disease. 


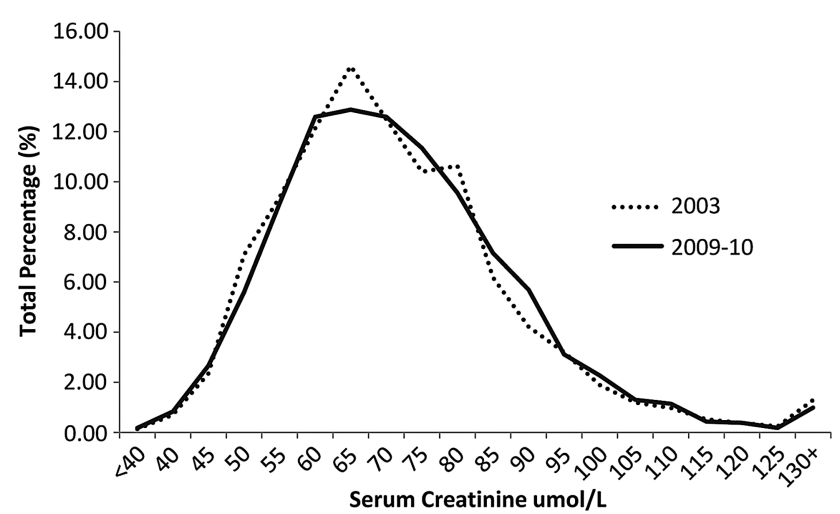

Figure 1 Distribution of serum creatinine ( $\mu \mathrm{mol} / \mathrm{L}$ ) for the 2003 and 2009/2010 survey data. Serum creatinine categories are grouped in bands of $5 \mu \mathrm{mol} / \mathrm{L}$ from $40 \mu \mathrm{mol} / \mathrm{L}$ to $130 \mu \mathrm{mol} / \mathrm{L}$. Serum creatinine values $<40 \mu \mathrm{mol} / \mathrm{L}$ and those $>130 \mu \mathrm{mol} / \mathrm{L}$ are grouped together.

There was an increase in the mean number of antihypertensive agents taken in individuals with: doctor-diagnosed hypertension (1.19 in 2003 to 2.01 in 2009/2010), doctordiagnosed hypertension and doctor-diagnosed diabetes (1.47-2.57); MDRD eGFR $<60 \mathrm{~mL} / \mathrm{min} / 1.73 \mathrm{~m}^{2}$ (1.30-1.77); and CKDEPI eGFR $<60 \mathrm{~mL} / \mathrm{min} / 1.73 \mathrm{~m}^{2}$
(1.35-1.93). The proportion taking RAS inhibitors in individuals with doctor-diagnosed diabetes, doctor-diagnosed hypertension, MDRD eGFR $<60 \mathrm{~mL} / \mathrm{min} / 1.73 \mathrm{~m}^{2}$ or CKDEPI eGFR $<60 \mathrm{~mL} / \mathrm{min} / 1.73 \mathrm{~m}^{2}$ also increased, as did overall lipid lowering agent use (online supplementary appendix 1).

The age-sex adjusted OR of having low eGFR (MDRD eGFR $<60 \mathrm{~mL} / \mathrm{min} / 1.73 \mathrm{~m}^{2}$ ) in 2009/2010 compared with 2003 was $0.84(95 \%$ CI 0.72 to 0.98$)$ and fully adjusted was 0.75 ( 0.61 to 0.92 ; table 3$)$. The corresponding ORs for CKDEPI were 0.85 (0.72 to 1.00) and 0.73 (0.57 to 0.93 ; table 4 ).

Sensitivity analyses replacing doctor-diagnosed diabetes with HBAlc and doctor-diagnosed hypertension with diastolic and systolic BP made little difference to the adjusted ORs, as did the inclusion of lipid lowering agents. No interactions between period and diabetes or hypertension were identified.

\section{DISCUSSION}

These analyses show that CKD prevalence in England estimated by serum creatinine-based equations in England appeared to decrease from 2003 to $2009 / 2010$. This decrease was seen across all age groupings (except in men
Figure 2 Comparison of low eGFR (<60 mL/min $\left./ 1.73 \mathrm{~m}^{2}\right)$ prevalence difference for MDRD and CKDEPI equations between the 2003 and $2009 / 2010$ HSEs for each age group by gender. CKD, chronic kidney disease; CKDEPI, Chronic Kidney Disease Epidemiology Collaboration; eGFR estimated glomerular filtration rate; HSE, Health Survey for England; MDRD, Modified Diet in Renal Disease.
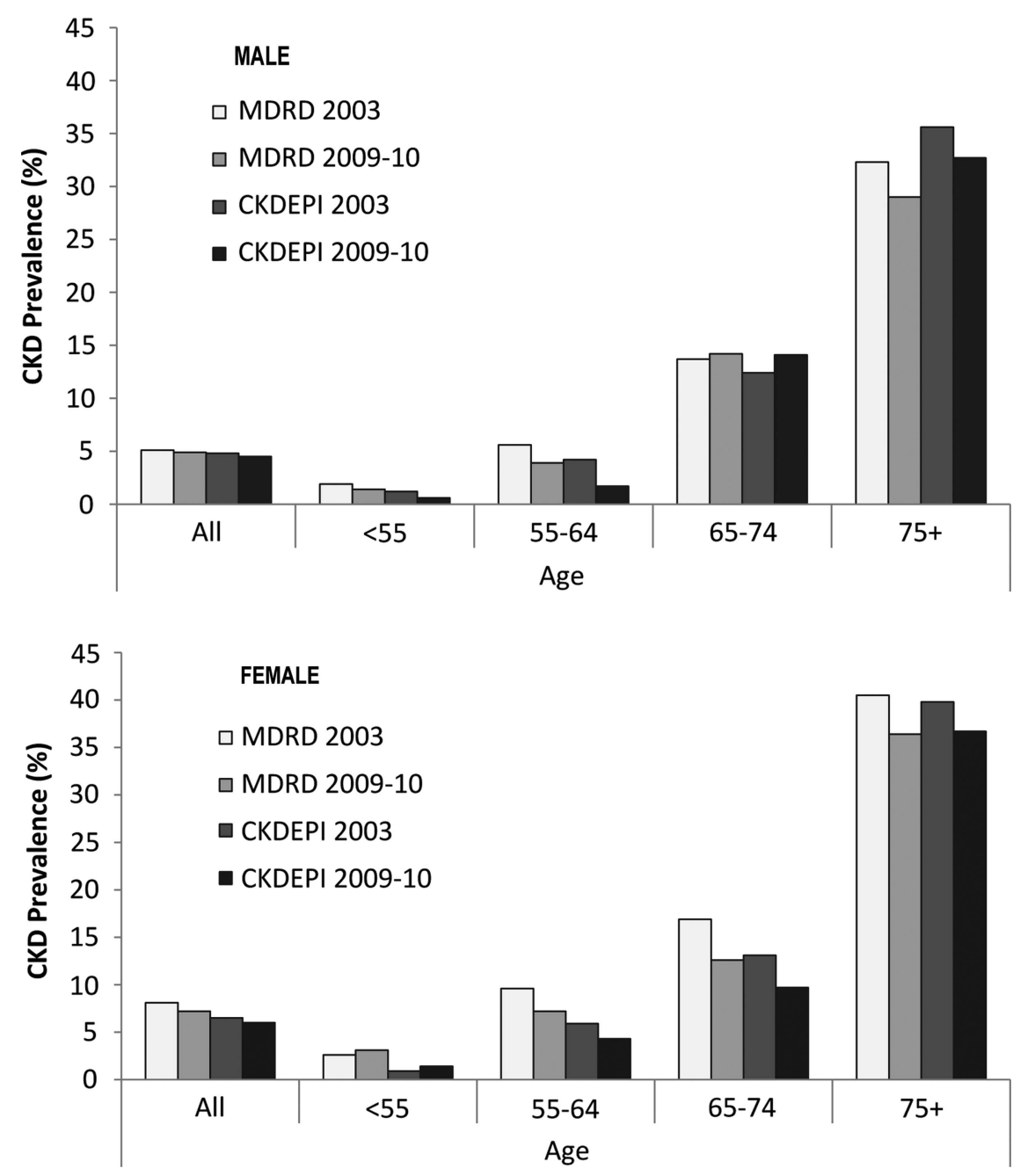
Table 3 Prevalence and associations of low eGFR $\left(<60 \mathrm{~mL} / \mathrm{min} / 1.73 \mathrm{~m}^{2}\right)$ by MDRD equation with adjustment for sociodemographic and clinical factors

\begin{tabular}{|c|c|c|c|c|c|}
\hline \multirow[b]{2}{*}{ Variable } & \multicolumn{5}{|l|}{ MDRD } \\
\hline & $\begin{array}{l}\text { Prevalence } \\
\text { of CKD (\%)† }\end{array}$ & OR (95\% Cl)‡ & OR (95\% Cl)§ & OR (95\% Cl)ף & OR (95\% Cl)t† \\
\hline \multicolumn{6}{|l|}{ HSE year } \\
\hline 2003 & 6.7 & 1 & 1 & 1 & 1 \\
\hline 2009-2010 & 6.0 & $0.84(0.72 \text { to } 0.98)^{\star}$ & $0.84(0.73 \text { to } 0.99)^{\star}$ & $0.75(0.61 \text { to } 0.92)^{\star \star}$ & 0.75 (0.61 to 0.92$)^{\star \star}$ \\
\hline \multicolumn{6}{|c|}{ (10, } \\
\hline $16-34$ & 0.2 & 1 & 1 & 1 & 1 \\
\hline $35-54$ & 2.1 & $10.8(5.3 \text { to } 22.0)^{\star *}$ & $11.1(5.5 \text { to } 22.8)^{\star *}$ & $10.8(5.0 \text { to } 23.4)^{* *}$ & $10.7(4.9 \text { to } 23.2)^{\star *}$ \\
\hline $55-64$ & 6.8 & $37(18 \text { to } 75)^{\star \star *}$ & $36(18 \text { to } 73)^{\star \star}$ & $33(15 \text { to } 72)^{\star *}$ & $32(14 \text { to } 69)^{\star *}$ \\
\hline $65-74$ & 14.5 & $87(43 \text { to } 175)^{\star *}$ & $82(40 \text { to } 167)^{\star *}$ & $65(30 \text { to } 143)^{\star *}$ & $62(28 \text { to } 135)^{\star *}$ \\
\hline $75+$ & 35.6 & $276(138 \text { to } 555)^{\star *}$ & $247(122 \text { to } 501)^{\star *}$ & $216(99 \text { to } 470)^{\star *}$ & $202(93 \text { to } 440)^{* *}$ \\
\hline \multicolumn{6}{|l|}{ Sex } \\
\hline Male & 5.0 & 1 & 1 & 1 & 1 \\
\hline Female & 7.7 & $1.42(1.22 \text { to } 1.65)^{\star \star}$ & $1.37(1.17 \text { to } 1.60)^{\star \star}$ & $1.69(1.36 \text { to } 2.10)^{\star *}$ & $1.66(1.34 \text { to } 2.06)^{\star \star}$ \\
\hline \multicolumn{6}{|c|}{ ( } \\
\hline White & 6.8 & - & 1 & 1 & 1 \\
\hline South Asian & 1.7 & - & $0.83(0.43$ to 1.59$)$ & $0.73(0.33$ to 1.60$)$ & $0.71(0.32$ to 1.56$)$ \\
\hline Black & 1.7 & - & $0.38(0.15$ to 1.00$)$ & 0.33 (0.09 to 1.19$)$ & $0.32(0.09$ to 1.16$)$ \\
\hline Other & 1.6 & - & 0.81 (0.29 to 2.30$)$ & 0.64 (0.17 to 2.46$)$ & 0.64 (0.17 to 2.44$)$ \\
\hline \multicolumn{6}{|l|}{ Tenure } \\
\hline Own & 6.3 & - & 1 & 1 & 1 \\
\hline Rent & 6.6 & - & $1.34(1.11 \text { to } 1.60)^{\star \star}$ & $1.23(0.97$ to 1.57$)$ & 1.23 (0.96 to 1.56$)$ \\
\hline \multicolumn{6}{|l|}{ Education } \\
\hline Degree level & 2.4 & - & 1 & 1 & 1 \\
\hline Below degree & 4.4 & - & 1.31 (0.99 to 1.74$)$ & 1.15 (0.83 to 1.60$)$ & 1.20 (0.84 to 1.70$)$ \\
\hline None & 14.9 & - & $1.52(1.13 \text { to } 2.04)^{\star \star}$ & $1.20(0.84$ to 1.70$)$ & $1.23(0.96$ to 1.57$)$ \\
\hline \multicolumn{6}{|l|}{ Smoking } \\
\hline Never & 6.1 & - & - & 1 & 1 \\
\hline Ex-smoker & 10.1 & - & - & 1.17 (0.91 to 1.49$)$ & 1.15 (0.85 to 1.54$)$ \\
\hline Current smoker & 3.2 & - & - & $1.02(0.75$ to 1.38$)$ & $1.04(0.80$ to 1.40$)$ \\
\hline \multicolumn{6}{|l|}{ BMI $\left(\mathrm{kg} / \mathrm{m}^{2}\right)$} \\
\hline Normal $(<25)$ & 3.4 & - & - & 1 & 1 \\
\hline Overweight (25-30) & 6.6 & - & - & 1.16 (0.91 to 1.49$)$ & 1.15 (0.90 to 1.47$)$ \\
\hline Obese $(>30)$ & 8.4 & - & - & $1.31(0.99$ to 1.71$)$ & 1.26 (0.96 to 1.65$)$ \\
\hline \multicolumn{6}{|l|}{ HDL cholesterol } \\
\hline Continuous & - & - & - & $0.51(0.38 \text { to } 0.67)^{\star *}$ & $0.51(0.38 \text { to } 0.68)^{\star \star}$ \\
\hline \multicolumn{6}{|l|}{ Total cholesterol } \\
\hline Continuous & - & - & - & 0.91 (0.84 to 1.00$)$ & $0.92(0.84$ to 1.00$)$ \\
\hline \multicolumn{6}{|c|}{ Doctor-diagnosed diabetes } \\
\hline No & 5.9 & - & - & 1 & 1 \\
\hline Yes & 17.3 & - & - & 1.42 (0.92 to 2.22$)$ & $1.36(0.87$ to 2.11$)$ \\
\hline \multicolumn{6}{|c|}{ Doctor-diagnosed hypertension } \\
\hline No & 4.0 & - & - & - & 1 \\
\hline Yes & 13.3 & - & - & - & $1.27(1.03 \text { to } 1.55)^{\star}$ \\
\hline
\end{tabular}

${ }^{*} p<0.05 ;{ }^{* *} p<0.01$.

†Prevalence for the combined 2003 and 2009-2010 HSEs.

$\ddagger$ Adjusted for age and sex.

§Adjusted for age, sex, ethnicity, tenure and education.

IAdjusted for age, sex, ethnicity, tenure, education, smoking, BMI, HDL cholesterol, total cholesterol and doctor-diagnosed diabetes.

††Adjusted for age, sex, ethnicity, tenure, education, smoking, BMI, HDL cholesterol, total cholesterol, doctor-diagnosed diabetes and doctor-diagnosed hypertension.

BMI, body mass index; CKD, chronic kidney disease; eGFR estimated glomerular filtration rate; HDL, high-density lipoprotein; HSE, Health Survey for England; MDRD, Modified Diet in Renal Disease.

aged 65-74), for CKD defined by MDRD and CKDEPI eGFR equations was more pronounced for the MDRD equation and occurred despite the increased prevalence of diabetes and obesity. ${ }^{21}$ Using the CKDEPI equation in place of MDRD to define CKD resulted in a lower prevalence of CKD. While it reduced overall prevalence, the CKDEPI equation identified more individuals aged $75+$ with CKD compared with the MDRD equation. ${ }^{22} 23$ 
Table 4 Prevalence and associations of low eGFR $(<60)$ by CKDEPI equation with adjustment for sociodemographic and clinical factors

\begin{tabular}{|c|c|c|c|c|c|}
\hline \multirow[b]{2}{*}{ Variable } & \multicolumn{5}{|l|}{ CKDEPI } \\
\hline & $\begin{array}{l}\text { Prevalence } \\
\text { of CKD }(\%) \dagger\end{array}$ & OR $(95 \% \mathrm{Cl}) \ddagger$ & OR $(95 \% \mathrm{Cl}) \S$ & OR $(95 \% \mathrm{Cl}) \pi$ & OR $(95 \% \mathrm{Cl}) \mathrm{tt}$ \\
\hline \multicolumn{6}{|l|}{ HSE year } \\
\hline 2003 & 5.7 & 1 & 1 & 1 & 1 \\
\hline 2009-2010 & 5.2 & 0.85 (0.72 to 1.00$)$ & 0.86 (0.72 to 1.01$)$ & $0.73(0.57 \text { to } 0.93)^{\star}$ & $0.73(0.57 \text { to } 0.93)^{*}$ \\
\hline \multicolumn{6}{|c|}{ (1) } \\
\hline $16-34$ & 0.1 & 1 & 1 & 1 & 1 \\
\hline $35-54$ & 1.0 & $15.1(4.5 \text { to } 51.4)^{\star *}$ & $16.1(4.7 \text { to } 55.0)^{\star *}$ & $13.8(4.0 \text { to } 47.2)^{\star *}$ & $13.5(3.9 \text { to } 46.5)^{* *}$ \\
\hline $55-64$ & 4.2 & $67(20 \text { to } 225)^{\star \star}$ & $67(20 \text { to } 227)^{\star \star}$ & $55(16 \text { to } 190)^{\star \star}$ & $52(15 \text { to } 177)^{\star *}$ \\
\hline $65-74$ & 12.5 & $219(66 \text { to } 725)^{\star *}$ & $219(65 \text { to } 731)^{\star *}$ & $162(47 \text { to } 553)^{\star *}$ & $151(44 \text { to } 517)^{\star *}$ \\
\hline $75+$ & 36.8 & $890(269 \text { to } 2938)^{\star \star *}$ & $844(253 \text { to } 2808)^{\star *}$ & $754(222 \text { to } 2559)^{\star \star}$ & $693(203 \text { to } 2355)^{\star \star}$ \\
\hline \multicolumn{6}{|c|}{ - } \\
\hline Male & 4.6 & 1 & 1 & 1 & 1 \\
\hline Female & 6.3 & 1.15 (0.97 to 1.36$)$ & 1.11 (0.93 to 1.31$)$ & $1.31(1.01 \text { to } 1.68)^{*}$ & $1.28(1.00 \text { to } 1.65)^{\star}$ \\
\hline \multicolumn{6}{|l|}{ Ethnic } \\
\hline White & 5.8 & - & 1 & 1 & 1 \\
\hline South Asian & 1.4 & - & $0.93(0.43$ to 2.00$)$ & 0.89 (0.35 to 2.42$)$ & 0.85 (0.34 to 2.16$)$ \\
\hline Black & 2.0 & - & $0.56(0.23$ to 1.39$)$ & $0.55(0.16$ to 1.82$)$ & $0.53(0.16$ to 1.77$)$ \\
\hline Other & 1.6 & - & $1.19(0.40$ to 3.56$)$ & $1.13(0.29$ to 4.41$)$ & $1.13(0.29$ to 4.41$)$ \\
\hline \multicolumn{6}{|l|}{ Tenure } \\
\hline Own & 5.3 & - & 1 & 1 & 1 \\
\hline Rent & 6.0 & - & $1.44(1.19 \text { to } 1.75)^{\star \star}$ & 1.29 (0.98 to 1.69$)$ & 1.28 (0.97 to 1.69$)$ \\
\hline \multicolumn{6}{|l|}{ Education } \\
\hline Degree level & 1.8 & - & 1 & 1 & 1 \\
\hline Below degree & 3.6 & - & 1.36 (0.97 to 1.90$)$ & 1.05 (0.69 to 1.58$)$ & 1.04 (0.69 to 1.58 ) \\
\hline None & 13.6 & - & $1.51(1.08 \text { to } 2.13)^{\star}$ & $1.12(0.76$ to 1.66$)$ & $1.11(0.75$ to 1.65$)$ \\
\hline \multicolumn{6}{|c|}{ (1) } \\
\hline Never & 5.2 & - & - & 1 & 1 \\
\hline Ex-smoker & 9.0 & - & - & 1.09 (0.77 to 1.55$)$ & 1.07 (0.75 to 1.52$)$ \\
\hline Current smoker & 2.6 & - & - & $0.80(0.70$ to 1.41$)$ & $0.79(0.54$ to 1.14$)$ \\
\hline \multicolumn{6}{|l|}{ BMI $\left(\mathrm{kg} / \mathrm{m}^{2}\right)$} \\
\hline Normal $(<25)$ & 2.7 & - & - & 1 & 1 \\
\hline Overweight (25-30) & 5.5 & - & - & $1.14(0.86$ to 1.51$)$ & $1.12(0.85$ to 1.49$)$ \\
\hline Obese $(>30)$ & 7.2 & - & - & $1.31(0.96$ to 1.80$)$ & $1.25(0.91$ to 1.72$)$ \\
\hline \multicolumn{6}{|l|}{ HDL cholesterol } \\
\hline Continuous & - & - & - & $0.40(0.29 \text { to } 0.56)^{\star *}$ & $0.40(0.29 \text { to } 0.57)^{\star *}$ \\
\hline \multicolumn{6}{|l|}{ Total cholesterol } \\
\hline Continuous & - & - & - & $0.93(0.84$ to 1.04$)$ & $0.94(0.86$ to 1.04$)$ \\
\hline \multicolumn{6}{|c|}{ Doctor-diagnosed diabetes } \\
\hline No & 5.0 & - & - & 1 & 1 \\
\hline Yes & 16.3 & - & - & 1.55 (0.96 to 2.48$)$ & 1.46 (0.91 to 2.35$)$ \\
\hline \multicolumn{6}{|c|}{ Doctor-diagnosed hypertension } \\
\hline No & 3.1 & - & - & - & 1 \\
\hline Yes & 12.3 & - & - & - & $1.33(1.05 \text { to } 1.67)^{\star \star}$ \\
\hline
\end{tabular}

${ }^{*} p<0.05 ;{ }^{* *} p<0.01$.

†Prevalence for the combined 2003 and 2009-2010 HSEs.

†Adjusted for age and sex.

$\S$ Adjusted for age, sex, ethnicity, tenure and education.

ПAdjusted for age, sex, ethnicity, tenure, education, smoking, BMI, HDL cholesterol, total cholesterol and doctor-diagnosed diabetes.

††Adjusted for age, sex, ethnicity, tenure, education, smoking, BMI, HDL cholesterol, total cholesterol, doctor-diagnosed diabetes and doctor-diagnosed hypertension.

BMI, body mass index; CKD, chronic kidney disease; CKDEPI, Chronic Kidney Disease Epidemiology Collaboration; eGFR estimated glomerular filtration rate; HDL, high-density lipoprotein; HSE, Health Survey for England.

The 2003, 2009 and 2010 HSEs were nationally representative samples, with the 2009/2010 data pooled over 2 years to increase the numbers and precision of estimates. The age-sex characteristics of the different study periods sampled were similar. The surveys used standardised protocols for measurement by trained interviewers and nurses. All samples were tested in the same laboratory with standardised assays. The analyses enable a 
longitudinal comparison of CKD estimates across different age-sex groupings and the application and comparison of the two equations to derive eGFR. We accounted for the shift in measured creatinine on storage in the 2003 HSE serum creatinine data by introduction of a correction factor derived from analysis of the effect of storage using 2009 data. Non-response weighting was undertaken in the HSE for both surveyed periods to reduce response bias and account for missing data for individuals who did not have blood samples taken and hence had no serum creatinine value. We used the HSE study design and the non-response weights to provide national prevalence estimates at each period and adjusted for a wide range of sociodemographic factors, so residual confounding due to differences in sample characteristics is less likely. Moreover, the distribution of age groupings was similar for both periods; hence, it does not explain the observed eGFR differences. The ethnic composition of the surveys changed over time with a small fall in the white population, but we adjusted for this change in the analysis.

The study was limited by the cross-sectional nature of the HSE, which restricts the ability to infer causal relationships from the associations identified. However, the use of new, cross-sectional samples enables the measurement of general population CKD prevalence at different time points. A single sample was tested for serum creatinine in each survey, and therefore the persistence of reduced eGFR levels to confirm chronicity cannot be shown. This is standard practice in national surveys such as NHANES, whereas studies based on routine testing, such as the QICKD study, can assess chronicity. ${ }^{24}$ Given the individual variation in kidney function, more extreme values will be averaged out on repeated testing (regression to the mean), reducing the prevalence of low eGFR. ${ }^{25}$ The results may therefore slightly overestimate the prevalence of CKD. There were very few cases from the key minority ethnic groups to give robust data on ethnic differences in the prevalence of CKD. South Asians and black groups have higher rates of renal replacement but have been found to have a lower prevalence of CKD than Caucasians. ${ }^{26} 27$

The prevalence of stage $4 / 5$ CKD is likely to be underestimated as, while the HSE is able to adjust for nonresponse among the general population in private households, it may not fully account for some in whom more severe CKD (stage 4/5) will be more common. This includes people who were not able to give a blood or urine sample because of poor health and those who did not participate due to concurrent illness or hospitalisation, as well as those in residential care.

The absence of albuminuria data in the 2003 HSE is a major limitation, given its strong independent association with adverse outcomes and its use to stratify risk for prevention and management (eg, use of RAS inhibition). ${ }^{3}$ We have therefore been unable to estimate changes in the prevalence of albuminuria per se, in all CKD (stages $1-5)$, and fully assess prevention and management.
The fall in low prevalence of eGFR could be due to (1) chance, (2) the artefact of differences in the serum creatinine measurement, (3) changes in serum creatinine production rather than excretion by the kidney, (4) residual confounding by differences in sample characteristics not adjusted for by sample weighting and (5) the true fall in eGFR. The two sets of samples were analysed in multiple analytical runs over a 19-month time period, which could lead to differences in results; however, during this time period, the internal quality control data indicate that the assay was accurate when compared with the assigned target values and stable. We found a storage artefact on serum creatinine measurement and accounted for this by the introduction of a correction factor. A change in serum creatinine over time independent of the kidney function could be due to less muscle mass (leading to lower serum creatinine production); there is no evidence for this and it seems unlikely to have occurred at the population level.

A decline in dietary protein consumption from cooked meat could also lead to a change in serum creatinine. Statistics from the National Diet and Nutrition Survey show that meat consumption increased from 2001-2002 to 2008-2010 while protein intake remained virtually stable over the same period. ${ }^{28}$ The mean consumption of meat and meat products increased from $154 \mathrm{~g} /$ day in 2001-2002 to $194 \mathrm{~g} /$ day in 2008-2010; protein intake contributing to food energy for adults aged 19+ increased slightly from 16-17\% in 2001-2002 to $17-18 \%$ in $2008-2010$; meat and meat products contributed to $37-38 \%$ of all protein intake for adults aged 19-64, with little change compared to 2008-2010. Cooked meat consumption has been shown to increase serum creatinine in small case studies of volunteers and of patients with diabetic nephropathy, and hence national guidance is to avoid eating cooked meat for $12 \mathrm{~h}$ before a blood test for creatinine, ${ }^{29}$ but this was not done in HSE.

We used the HSE study design and non-response weights and adjusted for a wide range of sociodemographic factors, so residual confounding due to differences in sample characteristics differences is less likely. Moreover, the distribution of age groupings was similar for both periods, so it does not explain the observed eGFR differences.

Key risk groups for developing CKD are people with hypertension and/or diabetes, especially if they have albuminuria. In this study, there was evidence of modest reductions in the prevalence of hypertension, better control of hypertension in key groups, and greater use of RAS inhibitors that have antiproteinuric as well as BP lowering effects, though the period changes in eGFR remained after correction for changes in hypertension prevalence. There is evidence from some studies using HSE, primary care databases and QOF data, ${ }^{30-32}$ though not all, ${ }^{33}$ of improved hypertension control in the past decade. However, there are ethnic disparities with poorer control of BP in Black and South Asians who 
have a higher risk of progression to need RRT. ${ }^{34}$ The population salt consumption also fell during the past decade, which is likely to have influenced population BP. $^{35}{ }^{36}$ CKD prevalence could also fall if those identified with moderate CKD were treated more aggressively, especially those with hypertension and/or albuminuria, leading to increased eGFR in some people to above $60 \mathrm{~mL} / \mathrm{min} / 1.73 \mathrm{~m}^{2}$. The limited HSE data suggest better BP control and greater use of RAS inhibitors in those with eGFR $<60 \mathrm{~mL} / \mathrm{min} / 1.73 \mathrm{~m}^{2}$. Karunaratne et al examined BP control in those with and without CKD in a primary care population in Kent and showed that BP control had improved in patients with CKD over time pre and post the introduction of QOF and that it was greater than in non-CKD patients with hypertension. They also showed increased use of RAS inhibitors and other antihypertensive agents in patients with $\mathrm{CKD} .{ }^{37}$

There was evidence of increased lipid lowering agent use (indicative of increased statin use) and a small fall in population lipid levels. There is some evidence of renoprotective effects of statins in patients with CKD; A lower rate of decline in GFR was found in patients with renal disease who took antilipemic agents. ${ }^{38}$ In the Heart Protection Study, the use of the hypolipidemic drug simvastatin reduced the rise in slightly elevated creatinine over time in participants with diabetes and non-diabetic CKD. ${ }^{39}$ In the SHARP trial, allocation of the lipid lowering ezetimibe plus simvastatin in participants not already on dialysis at randomisation reduced the outcome of ESRD or a doubling of creatinine with an OR of 0.93 , though this was not statistically significant. ${ }^{40}$ In the GREACE trial, statin treatment prevented a decline in renal function in people with high blood lipids and coronary heart disease; patients not treated with statins showed a 5.2\% decrease in creatinine clearance, while patients treated with statins showed a $4.9 \%$ increase in creatinine clearance. ${ }^{41}$ However, our period changes were not altered by adjusting for statins (lipid lowering drugs) or lipid levels (HDL, total cholesterol). ${ }^{37}$

There are limited data from other countries with which to compare these findings. Coresh et al analysed the US NHANES surveys of 1988-1994 and 1999-2004, both of which collected albuminuria and eGFR data. The prevalence of albuminuria and MDRD eGFR $<60 \mathrm{~mL} / \mathrm{min} / 1.73 \mathrm{~m}^{2}$ increased, the latter from $5.6 \%$ to $8.1 \% .^{8}$ The albuminuria increase was explained by changes in levels of obesity, diabetes and hypertension, whereas such adjustment only partly explained the fall in eGFR. Changes in population serum creatinine explained most of the remainder of the eGFR changes; this was analysed by comparing the mean serum creatinine in young people aged 20-39 without diabetes or hypertension and this had increased across the surveys. ${ }^{9}$ The authors suggested that this rise in serum creatinine could be either due to residual laboratory assay differences or changes in dietary protein or muscle mass. Grams et al showed that prevalence of eGFR $<60 \mathrm{~mL} / \mathrm{min} / 1.73 \mathrm{~m}^{2}$ had also increased using the same survey data when eGFR was estimated using cystatin C, a marker of kidney function that is independent of muscle mass, and this was not explained by changes in demography, hypertension, diabetes or obesity, suggesting a true increase in low eGFR. ${ }^{41}$

We can compare the estimated national CKD prevalence for HSE with QOF returns which record diagnosed CKD in primary care. ${ }^{42}$ Prevalence has been increasing with improvements in detection and recording, and in 2010 it was $4.2 \%$. The figures are not directly comparable as comparing a single screened value versus routine testing with presumed allowance for chronicity, but this may suggest some underdiagnosis of CKD.

If this change in prevalence in England is true, then based on the HSE 2003 age-sex-specific estimates and 2001 and 2011 Census data, the estimated number of CKD cases (for those aged 16 and over) would be 2.62 million based on the MDRD equation, falling by 0.03 million for 2009/2010. Equivalent figures for CKDEPI eGFR $<60 \mathrm{~mL} / \mathrm{min} / 1.73 \mathrm{~m}^{2}$ are 2.23 million and 0.02 million increase, respectively. The impact of such changes would be twofold: a consistent pool of patients at risk of progressing to need RRT; and a contribution to consistent cardiovascular incidence and mortality. The former is supported by stabilised acceptance rates onto RRT in England. ${ }^{4}$

\section{CONCLUSIONS}

The prevalence of a low eGFR appears to have decreased in England from 2003 to 2009/2010, despite increases in obesity and diabetes. It is unclear why this has occurred and it is difficult to infer directly that this is due to current policies to improve prevention of CKD and the identification and management of people with CKD. There is a need for repeated national prevalence estimates to further assess CKD patterns over time, including measures of albuminuria and of cystatin $\mathrm{C}$, both of which were available in HSE 2009 and 2010.

\section{Author affiliations}

${ }^{1}$ Faculty of Social and Human Sciences, Department of Geography, University of Southampton, Southampton, UK

${ }^{2}$ Faculty of Medicine, Academic Unit of Primary Care and Population Sciences, University of Southampton, Southampton, UK

${ }^{3}$ Research Department of Epidemiology and Public Health, University College London, London, UK

${ }^{4}$ Renal Unit, Salford Royal NHS Foundation Trust, Salford, UK

${ }^{5}$ Department of Clinical Biochemistry, Royal Victoria Infirmary, Newcastle Upon Tyne Hospitals NHS Foundation Trust, Newcastle Upon Tyne, UK

Acknowledgements Scott Harris contributed to the production of the regression equation that was applied to the 2003 serum creatinine samples as a correction factor.

Contributors GRA was involved in the analysis and interpretation of the data. PJR drafted the paper. GRA, PJR, SF and GM made substantial contributions to the study conception and design. JSM co-ordinated the Health Surveys for England. DO provided background information on chronic kidney disease policy. JD conducted the laboratory analyses. All authors critically reviewed the paper and were involved in the drafting and approval of the manuscript. GRA is the guarantor. 
Funding Kidney function testing in the Health Surveys for England was funded by NHS Kidney Care.

Competing interests GRA is funded by a University of Southampton PhD scholarship.

Ethics approval Approval was obtained from the London Multi-Centre Research Ethnics Committee for the 2003 survey (HSE 2003 ref MREC/02/2/ 72) and approval was obtained from the Oxford B Research Ethics Committee for both 2009 and 2010 surveys (HSE 2009 ref 08/H0605/103, HSE 2010 ref 09/H0605/73)

Provenance and peer review Not commissioned; externally peer reviewed.

Data sharing statement The HSE 2003, 2009 and 2010 are archived with the UK Data Service. The Technical Appendix, statistical code and data set are available from the corresponding author Grant Aitken at G.Aitken@soton.ac. uk. Creatinine measurements for the HSE 2003 undertaken for this study will be archived in due course.

Open Access This is an Open Access article distributed in accordance with the Creative Commons Attribution Non Commercial (CC BY-NC 4.0) license, which permits others to distribute, remix, adapt, build upon this work noncommercially, and license their derivative works on different terms, provided the original work is properly cited and the use is non-commercial. See: http:// creativecommons.org/licenses/by-nc/4.0/

\section{REFERENCES}

1. Couser WG, Remuzzi G, Mendis S, et al. The contribution of chronic kidney disease to the global burden of major noncommunicable diseases. Kidney Int 2011;80:1258-70.

2. Kidney Disease Improving Global Outcomes (KDIGO). Clinical Practice Guideline for the evaluation and management of chronic kidney disease. Kidney Int Supp/ 2013;3:1-150.http://www.kdigo.org/ clinical_practice_guidelines/pdf/CKD/KDIGO_2012_CKD_GL.pdf (accessed 16 Mar 2014).

3. Matsushita $\mathrm{K}$, van der Velde $\mathrm{M}$, Astor BC et al. Association of estimated glomerular filtration rate and albuminuria with all-cause and cardiovascular mortality in general population cohorts: a collaborative meta-analysis. Lancet 2010;375:2073-81.

4. Castledine C, Casula A, Fogarty D. UK Renal Registry 14th Annual Report: Chapter 2 UK RRT Prevalence in 2010: national and centre-specific analyses. UK Renal Registry, 2011. http://www. renalreg.com/Report-Area/Report\%202011/Chap02_Renal11_web. pdf. (accessed 16 Mar 2014).

5. Kerr M, Bray B, Medcalf $\mathrm{J}$, et al. Estimating the financial cost of chronic kidney disease to the NHS in England. Nephrol Dial Transplant 2012;27(Suppl 3):iii73-80.

6. De Lusignan $S$, Chan $T$, Stevens $P$, et al. Identifying patients with chronic kidney disease from general practice computer records. Fam Pract 2005;22:234-41.

7. Mindell J, Biddulph JP, Hirani V, et al. Cohort profile: the health survey for England. Int J Epidemiol 2012;41:1585-93.

8. Roth M, Roderick P, Mindell J. Kidney disease and renal function. In: Craig R, Mindell J, eds. Health survey for England 2010. Leeds: NHS Information Centre, 2011. Chapter 8, pp 1-27.

9. Coresh J, Selvin E, Stevens LA, et al. Prevalence of chronic kidney disease in the United States. JAMA 2007;298:2038-47.

10. Fox CS, Larson MG, Leip EP, et al. Predictors of new onset kidney disease in a community-based population. JAMA 2004;291:7844-50.

11. Ejerblad $\mathrm{E}$, Fored MC, Linblad $\mathrm{P}$, et al. Obesity and risk for chronic renal failure. J Am Soc Nephrol 2006;17:1695-702.

12. The National Service Framework for Renal Services. Part two: chronic kidney disease, acute renal failure and end of life care. London: Department of Health, 2005. https://www.gov.uk/ government/uploads/system/uploads/attachment_data/file/199002/ National_Service_Framework_for_Renal_Services_Part_Two_Chronic_Kidney_Disease_Acute_Renal_Failure_and_End_of_Life Care.pdf (accessed 16 Mar 2014).

13. Quality and outcomes framework guidance for GMS contract 2011/ 12. Delivering investment in general practice. London: NHS Employers and British Medical Association, 2011. http://www. nhsemployers.org/Aboutus/Publications/Documents/QOF_guidance GMS contract 2011_12.pdf (accessed 16 Mar 2014).

14. NHS health check programme best practice guidance. London: Department of Health, 2013. http://www.healthcheck.nhs.uk/ commissioners and healthcare professionals/national guidance/ (accessed 16 Mar 2014).

15. Sproston K, Primatesta P. Health survey for England 2003. Volume 3: methodology and documentation. London: The Stationery Office, 2004. http://webarchive.nationalarchives.gov.uk/20130107105354/ http://www.dh.gov.uk/prod consum dh/groups/dh digitalassets/@ dh/@en/documents/digitalasset/dh_4098912.pdf (accessed 16 Mar 2014).

16. Craig R, Hirani V. Health survey for England 2009. Health and lifestyles. Leeds: Health and Social Care Information Centre, 2010. http://www.hscic.gov.uk/pubs/hse09report (accessed 16 Mar 2014).

17. Matsushita K, Mahmoodi BK, Woodward M, et al. Comparison of risk prediction using the CKD-EPI equation and the MDRD study equation for estimated glomerular filtration rate. JAMA 2012;307:1941-51.

18. Levey AS, Stevens LA, Schmid $\mathrm{CH}$, et al. A new equation to estimate glomerular filtration rate. Ann Intern Med 2009;150:604-12.

19. Levey AS, Coresh J, Greene T, et al. Using standardized serum creatinine values in the modification of diet in renal disease study equation for estimating glomerular filtration rate. Ann Intern Med 2006;145:247-54.

20. Gislefoss RE, Grimsrud TK, Mørkrid L. Long-term stability of serum components in the Janus Serum Bank. Scand J Clin Lab Invest 2008;68:402-9.

21. Hirani V, Zaninotto P, Primatesta P. Generalised and abdominal obesity and risk of diabetes hypertension and hypertension diabetes comorbidity in England. Public Health Nutr 2008;11:521-7.

22. O'Callaghan CA, Shine B, Lasserson DS. Chronic kidney disease: a large-scale population-based study of the effects of introducing the CKD-EPI formula for eGFR reporting. BMJ Open 2011;1:e000308.

23. Carter JL, Stevens PE, Irving JE, et al. Estimating glomerular filtration rate: comparison of the CKD-EPI and MDRD equations in a large UK cohort with particular emphasis on the effects of age. QJM 2011;104:839-47.

24. de Lusignan S, Gallagher $\mathrm{H}$, Chan $\mathrm{T}$, et al. The QICKD study protocol: a cluster randomised trial to compare quality improvement interventions to lower systolic BP in chronic kidney disease (CKD) in primary care. Implement Sci 2009;4:39.

25. Eriksen BO, Ingebretsen OC. The progression of chronic kidney disease: a 10year population based study of the effects of gender and age. Kidney Int 2006;69:375-82.

26. Roderick PJ, Raleigh VS, Hallam L, et al. The need and demand for Renal Replacement Therapy in ethnic minorities in England. $J$ Epidemiol Community Health 1996;50:334-9.

27. Dreyer G, Hull S, Aitken Z, et al. The effect of ethnicity on the prevalence of diabetes and associated chronic kidney disease. QJM 2009;102:261-9.

28. Bates B, Lennox A, Bates $C$, et al. National Diet and Nutrition Survey: headline results from Years 1 and 2 (combined) of the Rolling Programme (2008/09-2009/10). https://www.gov.uk/ government/uploads/system/uploads/attachment_data/file/216484/ dh_128550.pdf (accessed 22 Jun 2014).

29. National Collaborating Centre for Chronic Conditions. Chronic kidney disease: national clinical guideline for early identification and management in adults in primary and secondary care. National Collaborating Centre for Chronic Conditions. London: Royal College of Physicians, 2008.

30. Falaschetti $\mathrm{E}$, Chaudhury M, Mindell J, et al. Continued improvement in hypertension management in England: results from the Health Survey for England 2006. Hypertension 2009;53:480-6.

31. Ashworth M, Medina J, Morgan M. Effect of social deprivation on blood pressure monitoring and control in England: a survey of data from the quality and outcomes framework. BMJ 2008;337:a2030.

32. Carey IM, Nightingale CM, DeWilde S, et al. Blood pressure recording bias during a period when the Quality and Outcomes Framework was introduced. J Hum Hypertens 2009;23:764-7.

33. Serumaga B, Ross-Degnan D, Avery AJ, et al. Effect of pay for performance on the management and outcomes of hypertension in the United Kingdom: interrupted time series analysis. BMJ 2011;342:d108

34. Millett C, Gray J, Bottle A, et al. Ethnic disparities in blood pressure management in patients with hypertension after the introduction of pay for performance. Ann Fam Med 2008;76:490-6.

35. Millett C, Laverty AA, Stylianou N, et al. Impacts of a national strategy to reduce population salt intake in England: serial cross sectional study. PLOS ONE 2012:7; e29836.

36. Sadler K, Nicholson S, Steer T, et al. National Diet and Nutrition Survey-Assessment of Dietary Sodium Levels among Adults (aged 19-64years) in England, 2011. London: Department of Health, 2012 https://www.gov.uk/government/uploads/system/uploads/attachment data/file/213420/Sodium-Survey-England-2011_Text_to-DH_FINAL1. pdf (accessed 16 Mar 2014). 
37. Karunaratne K, Stevens $\mathrm{P}$, Irving J, et al. The impact of pay for performance on the control of blood pressure in people with chronic kidney disease stage 3-5. Nephrol Dial Transplant 2013;28:2107-16.

38. Fried LF, Orchard TJ, Kasiske BL. Effect of lipid reduction on the progression of renal disease: a meta-analysis. Kidney Int 2001;59 (1):260-9.

39. Heart Protection Study Collaborative Group. MRC/BHF Heart Protection Study of cholesterol lowering with simvastatin in 20,536 high-risk individuals: a randomised placebo-controlled trial. Lancet 2002;360:7-22.

40. Lewis D. Effect of LDL-cholesterol lowering on renal disease progression among patients with chronic kidney disease: results of the Study of Heart And Renal Protection (SHARP). Clin Kidney $J$ 2011;4(Suppl 2):113-16.

41. Mikhailidis DP, Wierzbicki AS. Treatment with atorvastatin to the National Cholesterol Educational Program goal versus 'usual' care in secondary coronary heart disease prevention. The GREek Atorvastatin and Coronary-heart-disease Evaluation (GREACE) study. Curr Med Res Opin 2002;18:215-19.

42. Grams ME, Juraschek SP, Selvin E, et al. Trends in the prevalence of reduced eGFR in the United States: comparison of creatinine and cystatin c based estimates. Am J Kidney Dis 2013;62:253-60. Health \& Social Care Information Centre: Quality and Outcomes Framework-2009-10 England level. http://www.hscic.gov.uk/ catalogue/PUB04431 (accessed 22 Jun 2014). 